Int. J. Dev. Biol. 57: 1-12 (2013)

doi: $10.1387 / \mathrm{ijdb} .120115 \mathrm{ls}$

\title{
Signaling pathways during maintenance and definitive endoderm differentiation of embryonic stem cells
}

\author{
LINA SUI, LUC BOUWENS* and JOSUÉ K. MFOPOU \\ Cell Differentiation Unit, Diabetes Research Center, Vrije Universiteit Brussel, Brussels, Belgium
}

\begin{abstract}
Embryonic stem cells (ESCs) have the potential to be used as unlimited resources for tissue replacement therapy, thereby compensating for organ donor shortage. To reach this goal, the molecular principles governing early differentiation events in the developing embryo need to be addressed, understood and properly implemented in vitro. Studies carried out in several vertebrate models have established that Nodal/Activin A, BMP, WNT and FGF signaling pathways regulate early embryo development and that these pathways are similarly used during germ layer formation by cultured ESCs. However, differences have also been identified in the way these pathways function or interact in mouse vs. human ESCs, making it sometimes difficult to extrapolate findings from one system to the other. In this review, we discuss and compare the role of the relevant signaling pathways and their crosstalk during undifferentiated growth and during the endoderm differentiation of mouse and human ESCs.
\end{abstract}

KEY WORDS: human embryonic stem cell, mouse embryonic stem cells definitive endoderm, FGF, Nodal/Activin A

\section{Introduction}

Mouse embryonic stem cells (mESCs) were first isolated in1981 and derived from the inner cell mass (ICM) of pre-implantation blastocyst stage embryo (Evans and Kaufman, 1981, Martin, 1981). They are able to self-renew and to differentiate into any somatic cell type in culture or following transplantation in vivo. With regards to these properties, the derivation of human embryonic stem cells (hESCs) (Thomson et al., 1998) was immediately followed by efforts to differentiate them into desired cell types such as neurons (Cho et al., 2008, Di Giorgio et al., 2008, Mueller et al., 2005, Nat and Dechant, 2011), cardiomyocytes (Laflamme et al., 2007, Mummery et al., 2007, Parsons et al., 2011, Xu et al., 2009), hepatocytes (Agarwal et al., 2008, Hay et al., 2008, Touboul et al., 2010) and pancreatic endocrine cells (Assady et al., 2001, Cai et al., 2010, D’Amour et al., 2006, Jiang et al., 2007a, Jiang et al., 2007b, Johannesson et al., 2009, Kroon et al., 2008, Mfopou et al., 2010a, Xu et al., 2011, Zhang et al., 2009) in view of their future use to replace dysfunctional or missing cells in diseases. ESCs are not only used as a potential tool for cell replacement therapy, disease modeling, drug discovery and toxicity testing; they also serve as a model to understand the molecular mechanisms of germ layer formation during early development, a pivotal process that dictates further ontogeny of organ-specific cells. Three germ layers, namely endoderm, mesoderm and ectoderm, are specified during gastrulation in the developing embryo, thereby setting up the landmarks for future tissues and organs. Similarly, the specification of these germ layer equivalents in vitro appears as one of the first and most important events required during ESC differentiation for the generation of desired cell types. Considering the endoderm, a number of signaling pathways have been identified that control its differentiation in lower and higher vertebrates, including Nodal/ Activin A, BMP, WNT and FGF (Hansson et al., 2009, McLean et al., 2007, Morrison et al., 2008, Poulain et al., 2006, Rodaway et al., 1999, Rossant, 2008, Slack, 1994, Sumi et al., 2008, Vallier et al., 2009b, Xu et al., 2011, Zhang et al., 2008, Zheng et al., 2010). Although the contribution of these pathways is conserved among many species, their particular functions (inductive or repressive) and their activity timing can vary significantly, explaining in part the contrasting findings that have been described, for instance, between mESCs and hESCs. In the scope of this review, we aim at giving an overview of the current understanding of germ layer

Abbreviations used in this paper: BMP, bone morphogenetic protein; CDM, chemically defined medium; DE, definitive endoderm; ESC, embryonic stem cell; FGF, fibroblast growth factor; KSR, knockout serum replacement; LIF, leukemia inhibitory factor; MEF, mouse embryonic fibroblasts; PS, primitive streak; TGF-beta, transforming growth factor beta; WNT, wingless-type MMTV integration site family member.

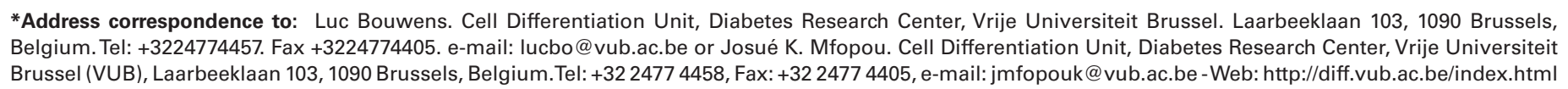


formation from mESCs and hESCs, with special focus on the definitive endoderm (DE).

\section{The signaling pathways maintaining undifferentiated ESCs status}

Mouse or human ESCs are essentially characterized by their ability to make multiple copies of themselves for long periods in culture (self-renewal), and to generate cells belonging to the three germ layers upon differentiation (pluripotency). These essential properties of mESCs and hESCs (Rossant, 2008, Vallier et al., 2009b) are actually under the control of signaling pathways that differ between the two species. Undifferentiated mESCs are mainly maintained under the control of LIF and BMP signaling (Chambers and Smith, 2004, Williams et al., 1988, Ying et al., 2003a), while $\mathrm{hESC}$ require Activin and FGF signaling to sustain long-term selfrenewal and pluripotency (Ding et al., 2010, Vallier et al., 2005, Xiao et al., 2006). However, these signaling pathways converge towards the activation of a core transcriptional network supporting self-renewal that is similar in both systems and involves Oct4, Nanog and Sox2 (Schnerch et al., 2010) (Fig.1).

The discrepancies observed between mESCs and hESCs in their requirements for undifferentiated growth cannot be accounted only to species differences, but they can be largely explained by the different developmental origins of these pluripotent cells. $\mathrm{hESC}$ are derived at a later stage than mESCs, at a point when epiblast differentiation is initiated. It is possible that the derivation of pluripotent stem cells from mouse ICM cells is facilitated by the

hESC
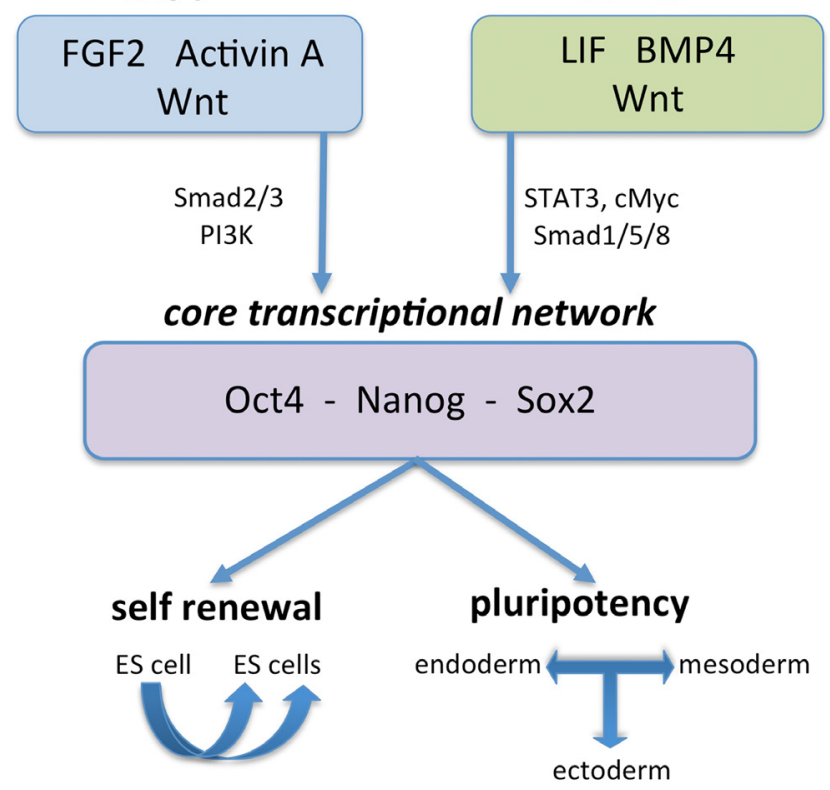

Fig. 1. Schematic representation of the differences in signaling pathways regulating self-renewal and pluripotency of human and mouse ESCs. Undifferentiated mESCs are mainly maintained under the control of LIF and BMP signaling, whereas hESCs are in need of Activin and FGF signaling to sustain long-term self-renewal and pluripotency. The Wnt signaling also plays a role in self-renewal of hESCs and mESCs, but its underlying mechanism is still to be addressed. These signaling pathways in both systems converge towards the activation of a core transcriptional network that involves Oct4, Nanog and Sox2. delayed implantation or embryonic diapause (Hondo and Stewart, 2005, Lopes et al., 2004, Renfree and Shaw, 2000) that exists in this specie but is absent in human embryo. Interestingly, pluripotent cells were also derived from mouse and rat post-implantation embryos and shown to share similar gene expression and signalling response patterns with hESCs and epiblast (Brons et al., 2007, Tesar et al., 2007). In addition to sharing signalling pathways for self-renewal with hESCs, epiblast stem cells (EpiSCs) also display similar culture characteristics including the requirement for passaging in clumps, the low clonal capacity and the reduced efficiency of chimera formation. Therefore mouse and rat EpiSCs are the exact developmental counterparts of hESCs and are considered to be "primed", on the contrary of mESCs that are in a "naïve" pluripotency state (Nichols et al., 2009). Given the ease of manipulation and the stable phenotype of "naïve" pluripotent stem cells in culture, current studies investigate the derivation of such cells from early human embryos (before the epiblast stage) as well as the conversion of current hESCs lines into a "naïve" state (Gu et al., 2012, Hanna et al., 2010, Zhou et al., 2010).

\section{Self-renewal and pluripotency in mESCs}

The mESCs were originally isolated from the ICM of early mouse blastocyst and maintained on mitotically inactivated mouse embryo fibroblasts (feeder layer) that contribute by secreting antidifferentiation cytokines such as BMP4 and LIF (Martin, 1981, Qi et al., 2004). LIF receptor, but not the ligand, is normally expressed by the ICM cells and is involved in the maintenance of pluripotency in the mouse embryo (Nichols et al., 1996). Interestingly, exogenous LIF combined with serum or BMP4 sustains self-renewal in feederfree culture of mESCs. In this setting and similar to its function during gastrulation, BMP4/SMAD pathway represses the default neural differentiation (Di-Gregorio et al., 2007), whereas in the absence of LIF it generates uniform sheets of flat cells (Kunath et al., 2007, Ying et al., 2003a). Together, LIF and BMP4 might suppress differentiation events triggered by autocrine FGF4-mediated ERK phosphorylation. This hypothesis led to the discovery that FGF inhibition (with SU5402 and PD184352) combined with GSK3 inhibition with CHIR99021 maintains pluripotency in serum-free and feeder-free conditions (Ying et al., 2008). These latter findings are concordant with previous observations that inhibition of FGF/MAPK improves self-renewal in mESCs (Burdon et al., 1999, Burdon et al., 2002, Kunath et al., 2007). Beside LIF and BMP4, WNT ligands expressed by mESCs and by feeder cells are also crucial for preventing mESCs differentiation, but similar to WNT stimulation by GSK3 inhibition, the exact mode of action is still a matter of debate (Sato et al., 2004, ten Berge et al., 2011, Wray et al., 2011, Ying et al., 2008). Indeed, the ICM cells also express few WNT ligands and their secreted antagonists, suggesting that this pathway plays a role in preimplantation development (Kemp et al., 2007).

\section{Self-renewal and pluripotency in hESCs}

The $\mathrm{hESC}$ are derived from blastocyst stage human embryos; they show activated Nodal/Activin, FGF and WNT pathways and have the potential for long-term maintenance in undifferentiated state and generation of three germ layer derivatives (Sato et al., 2004, Thomson et al., 1998, Xiao et al., 2006). Similar to LIF in $\mathrm{mESC}$, Activin A is sufficient and necessary for maintaining $\mathrm{hESC}$ pluripotency in long-term culture with $20 \%$ serum replacer (KSR), 
which contributes among others by activating the PI3K pathway (Li et al., 2007, McLean et al., 2007, Xiao et al., 2006), and recalls the function of Nodal signaling in maintaining an undifferentiated status of the epiblast (Camus et al., 2006, Granier et al., 2011, Mesnard et al., 2006). On the contrary, Activin A does not maintain pluripotency in a chemically defined medium (CDM), suggesting that both Activin A and activated PI3K are essential for undifferentiated hESCs (Vallier et al., 2005).

FGF signaling is crucial for embryonic development as revealed by peri-implantation lethality of several mutants and by the expression of FGF4 in the epiblast (reviewed in (Lanner and Rossant, 2010)). FGFs are released by hESCs and are also involved in the maintenance of their pluripotency via intracellular activation of PI3K/AKT and/or MAPK/ERK downstream pathways. On the contrary, FGF receptor inhibitor SU5402 induces hESC differentiation whereas active PI3K/AKT blocks endoderm differentiation induced by Activin A (Armstrong et al., 2006, Ding et al., 2010, Dvorak et al., 2005, Li et al., 2007, McLean et al., 2007). While investigating the molecular mechanisms of FGF-mediated hESC maintenance, MAPK/ERK was suggested as being required for pluripotency (Dvorak et al., 2005, Li et al., 2007); however a study by Ding et al., found that activated PI3K, rather than MAPK, mediates pluripotency in hESCs (Ding et al., 2010). These discrepancies might reside in the experimental models given that FGF2 starvation was performed for either $12 \mathrm{~h}$ or 5 days (Ding et al., 2010, Li et al., 2007). Since neither FGF nor Activin A alone is sufficient to maintain pluripotency in feeder-free conditions (Vallier et al., 2005), a crosstalk between signaling pathways is likely operative and regulates the growth of undifferentiated hESCs. For instance, Activin A and FGF2 supplementation combined with ERK1/2 inhibition allows for hESC self-renewal in CDM on collagen I coated surface ( $\mathrm{Na}$ et al., 2010). In this system, the absence of BMP4-like signals (usually present in KSR) and the inhibition of ERK phosphorylation exclude spontaneous differentiation towards mesendoderm and neural fates. This would indicate that a "ground state" (Ying et al., 2008) also exists for hESCs and its requirements are yet to be unravelled in vitro.

As mentioned above for mESCs, active WNT signaling contributes to the maintenance of pluripotency during hESC culture (Sato et al., 2004, ten Berge et al., 2011). FGF2 can induce phosphorylation of GSK3 $\beta$ (a downstream target of PI3K), thereby activating the WNT pathway in hESCs. However, WNT gradually loses its ability to maintain undifferentiated hESCs in long-term culture, suggesting that it is not an anti-differentiation factor (Ding et al.,

\section{TABLE 1}

GROWTH FACTORS REQUIRED FOR SELF-RENEWAL IN PLURIPOTENT STEM CELLS DERIVED FROM THE EMBRYO

\begin{tabular}{|c|c|c|}
\hline Stem cells & $\begin{array}{l}\text { Main self-renewal } \\
\text { factors }\end{array}$ & Remarks \\
\hline mESCs & LIF, BMP4, WNT & $\begin{array}{l}\text { None of them could support long-term self-renewal in the } \\
\text { absence of others. } \\
\text { LIF+BMP4, LIF+WNT/ iGSK3 or WNT/iGSK3+iMAPK } \\
\text { maintain long-term pluripotency. }\end{array}$ \\
\hline hESCs & FGF, Activin A & $\begin{array}{l}\text { Alone, FGF or Activin A is not sufficient to maintain self- } \\
\text { renewal. } \\
\text { Their combination is sufficient and efficient. } \\
\text { Wnt is also expressed by hESCs but not essential for } \\
\text { pluripotency. }\end{array}$ \\
\hline m/rEpiSCs & FGF, Activin A & Similar to hESCs \\
\hline
\end{tabular}

iGSK3, inhibitor of GSK3; iMAPK, inhibitor of MAPK; m/rEpiSCs, mouse or rat epiblast stem cells.
2010, Dravid et al., 2005).

Although several studies identified specific pathways that regulate pluripotency in the developing embryo or in ESCs and paved the way for developing "optimal recipes" for undifferentiated growth in vitro (Table 1), the crosstalk between these pathways still needs to be further addressed in order to have a clear understanding of both systems, which will also warrant the high-quality of stem cell cultures by limiting spontaneous differentiation and chromosomal abnormalities.

\section{The signaling pathways in endoderm specification from ESCs}

Studies in developmental models such as zebrafish and mouse initially pointed towards the existence of a transit germ layer named mesendoderm that is present during early gastrulation, and is bipotential for endoderm and mesoderm (Lawson et al., 1991, Rodaway and Patient, 2001, Rodaway et al., 1999). The presence of such an intermediate germ layer was also suggested and its characteristics defined during in vitro differentiation of mESCs and hESCs (Tada et al., 2005). Interestingly, several signals involved in the differentiation of mESCs and hESCs into the primitive streak (PS), mesendoderm and then further into endoderm or mesoderm are conserved (Table 2). Therefore, despite the major differences between mESCs and hESCs maintenance, similar pathways control the differentiation into particular germ layers. This would constitute an asset for in vitro differentiation and would help crossing species borders with well-defined universal differentiation protocols. However, this is not always the case in practice. Because of its recent discovery, not enough data are available on the differentiation of EpiSCs into definitive endoderm. We therefore further discuss here the differentiation of DE from mESCs and hESCs in detail, with focus on conserved signaling pathways and their particularities in each system.

\section{Definitive endoderm differentiation in mESCs}

\section{Nodal/Activin A pathway}

The PS formation is an essential step prior to the generation of endoderm and mesoderm derivatives in vivo. Nodal/Activin A signaling is crucial for the induction of PS formation, given that this structure is absent in Nodal-/- mutant mouse embryo (Conlon et al., 1994, Zhou et al., 1993). In vitro, Nodal/Activin A induces anterior and posterior PS in a concentration-dependent manner both in adherent cultures of ESCs (Hansson et al., 2009, Tada et al., 2005, Yasunaga et al., 2005) and in embryoid bodies (EBs) maintained in suspension (Gadue et al., 2006, Kubo et al., 2004). For instance, high concentration of Activin A (10-100 $\mathrm{ng} / \mathrm{ml}$ ) favors anterior $\mathrm{PS}$ and further gives rise to $\mathrm{DE}$ if the stimulation persists. On the contrary, low concentration $(1-3 \mathrm{ng} / \mathrm{ml})$ mainly specifies posterior PS and then posterior mesoderm. Although this general principle applies to both adherent and suspension cultures and is concordant with Nodal/Activin A function in embryonic development (Schier, 2003, Tam et al., 2003), the expression of Gsc (mesendoderm and DE marker) induced by high dose of Activin $A$ is lower in EBs or in serum containing condition as compared to cells cultured in monolayer without serum (Tada et al., 2005). However, monolayer induction of DE in the absence of serum is severely restricted by the very poor cell survival ((Morrison et al., 
2008) and our personal observations). This discrepancy suggests that the undefined factors present in the serum as well as the cellular architecture formed in EB play a pivotal role on mesendoderm/ DE formation from mESCs following Activin A induction, primarily by providing survival signals.

\section{BMP pathway}

Similar to Nodal/Activin A, BMP also belongs to the TGF-beta superfamily of growth and differentiation factors. It blocks the default neural differentiation and maintains the undifferentiated state of mESCs in concert with LIF. In the absence of LIF, BMP4 regains its ability to induce mESCs differentiation, and its effect varies with the cellular spatial organisation. In adherent cultures, BMP4 induces surface ectoderm equivalents (Kunath et al., 2007, Ying et al., 2003a) as well as trophoblast-like cells (Hayashi et al., 2010); the latter having been widely thought not to develop from mESCs cultures (Beddington and Robertson, 1989). Moreover, BMP4 supplementation to EBs cultures led to the formation of posterior PS and mesodermal cells (Nostro et al., 2008, Pearson et al., 2008), which recalls its involvement in mesoderm differentiation during gastrulation (Hogan, 1996, Wells and Melton, 1999). This suggests that BMP4 is primarily an inducer of PS-like population expressing T (Brachyury) and Mixl1 (Fujiwara et al., 2001), and explains its supplementation in combination with Activin $A$ at the early stage of DE induction from mESCs (Morrison et al., 2008).

\section{WNT pathway}

Beside Nodal/Activin A signaling, the WNT pathway is also important for PS differentiation as revealed by its absence in WNT/- mutant mouse embryos (Barrow et al., 2007, Liu et al., 1999).
In vitro in serum-free medium, WNT signaling induces a posterior PS population both in monolayer cultures of mESCs and in EBs (Gadue et al., 2006, Nakanishi et al., 2009). Combination of WNT and Activin A improved DE induction as evaluated by Sox17 expression, but this effect is minimal if WNT is supplemented after the initiation of DE differentiation (Hansson et al., 2009). Accordingly, inhibition of WNT with Dkk1 reduced PS and DE formation in the presence of Activin A as indicated by low expression of Mixl1 and Sox17 (Hansson et al., 2009). These data are concordant with the in vivo findings that WNT signaling, similar to BMP4, is required for PS formation but is not an inducer of anterior lineages (Kemp et al., 2007).

\section{FGF pathway}

FGF signaling controls mESCs transition from pluripotency to lineage commitment, and blockade of this pathway results in the maintenance of pluripotency markers expression (Burdon et al., 1999, Kunath et al., 2007, Lanner and Rossant, 2010). Activation of the MAPK/ERK1/2 pathway induced by FGF signaling is required for neural specification of mESCs within a short time window, explaining why this has been considered as the default fate of spontaneously differentiating mESCs (Stavridis et al., 2007). Beside its role on ectodermal lineages, FGF signaling from autocrine or paracrine sources is also involved in mesodermal fate commitment (Ciruna and Rossant, 2001, Kunath et al., 2007). However, supplementation of mESCs cultures with FGF ligands does not induce PS and mesoderm formation in the absence of TGF-beta or Wnt signals (Zheng et al., 2010). To this end, the contribution of FGF signaling in DE differentiation is not direct as is the case for Activin A, but is integrated in a signaling network built from the

TABLE 2

\section{OVERVIEW OF THE EFFECTS OF INHIBITING OR ACTIVATING RELEVANT PATHWAYS ON GERM LAYER DIFFERENTIATION FROM EMBRYONIC STEM CELLS}

\begin{tabular}{|c|c|c|c|c|c|c|c|}
\hline \multirow[b]{2}{*}{ Stem cells } & \multirow[b]{2}{*}{ Pathways/Factors (References) } & \multicolumn{3}{|c|}{ Effect of pathway inhibition } & \multicolumn{3}{|c|}{ Effect of pathway activation } \\
\hline & & PS & DE & ME & PS & DE & ME \\
\hline \multirow[t]{5}{*}{ mESCs } & $\begin{array}{l}\text { Activin A/Nodal } \\
\text { (Gadue et al., 2006, Hansson et al., 2009, Kubo et al., 2004, } \\
\text { Tada et al., 2005, Yasunaga et al., 2005) }\end{array}$ & $x$ & $x$ & $x$ & $\begin{array}{l}\text { Low level } \Rightarrow \text { post. PS } \\
\text { High level } \Rightarrow \text { ant. PS }\end{array}$ & High level $\Rightarrow D E$ & Low level $\Rightarrow$ post. ME \\
\hline & $\begin{array}{l}\text { BMP4 } \\
\text { (Fujiwara et al., 2001, Hansson et al., 2009, Li et al., 2011, } \\
\text { Nostro et al., 2008, Pearson et al., 2008) }\end{array}$ & $\mathrm{N}$ & $\begin{array}{l}\text { With ActA and } \\
\text { WNT } \Rightarrow \mathrm{DE}\end{array}$ & $\mathrm{N}$ & PS & $x$ & post. ME \\
\hline & $\begin{array}{l}\text { WNT } \\
\text { (Gadue et al., 2006, Hansson et al., 2009, Nakanishi et al., 2009) }\end{array}$ & $x$ & $x$ & $\mathrm{~N}$ & PS & Marginal effect & post. ME \\
\hline & $\begin{array}{l}\text { FGF } \\
\text { (Hansson et al., 2009, Kunath et al., 2007, Morrison et al., 2008, } \\
\text { Zheng et al., 2010) }\end{array}$ & $x$ & $\mathrm{x}$ & $x$ & with inductive signal & with inductive signal & with inductive signal \\
\hline & $\begin{array}{l}\text { NOTCH } \\
\text { (Lowell et al., 2006, Nemir et al., 2006) }\end{array}$ & & & ME & & & \\
\hline \multirow[t]{5}{*}{ hESCs } & $\begin{array}{l}\text { Activin A/Nodal } \\
\text { (D'Amour et al. 2005; Smith et al. 2008; Sumi et al. 2008; } \\
\text { Borowiak et al. 2009) }\end{array}$ & $x$ & $x$ & $x$ & $\begin{array}{l}\text { Low level } \\
\Rightarrow \text { post. PS } \\
\text { High level } \\
\Rightarrow \text { ant. PS }\end{array}$ & High level $\Rightarrow D E$ & Low level $\Rightarrow$ post. ME \\
\hline & $\begin{array}{l}\text { BMP4 } \\
\text { (Phillips et al., 2007, Sumi et al., 2008, Takei et al., 2009, } \\
\text { Zhang et al., 2008) }\end{array}$ & PS & DE & $x$ & with Activin A & with Activin A & $\begin{array}{l}\text { Short time exposure or EB } \\
\Rightarrow \mathrm{ME}\end{array}$ \\
\hline & $\begin{array}{l}\text { WNT } \\
\text { (D'Amour et al., 2005, Sumi et al., 2008) }\end{array}$ & & & & PS & $\begin{array}{l}\text { With Noggin } \\
\Rightarrow D E\end{array}$ & post. ME \\
\hline & $\begin{array}{l}\text { FGF } \\
\text { (Ding et al., 2010, Na et al., 2010, Vallier et al., 2009b) }\end{array}$ & $x$ & $x$ & ME & with inductive signal & with inductive signal & with inductive signal \\
\hline & $\begin{array}{l}\text { NOTCH } \\
\text { (Hughes et al., 2009, Jang et al., 2008) }\end{array}$ & $x$ & & ME & & & \\
\hline
\end{tabular}


above described pathways (Activin, BMP, WNT) and involves the generation of the transient population of $\mathrm{PS} /$ mesendoderm cells as well as the commitment of these cells towards a DE fate (Hansson et al., 2009, Morrison et al., 2008).

\section{Crosstalk between signaling pathways during definitive endoderm differentiation from $\mathrm{mESCS}$}

Using monolayer and EB culture conditions, Morrison et al., showed that mESCs treated with Activin A plus BMP4 for the first 2 days and then with Activin A plus EGF for 5 days generated the highest proportion (up to $20 \%$ ) of DE cells (Morrison et al., 2008). Inhibition of Activin A signal blocks BMP4 induced PS differentiation, whereas continuous exposure to BMP4 after PS formation potentiates mesoderm formation over endoderm. Once specified, the mesoderm cannot be shifted back to DE by addition of Activin A (Pearson et al., 2008). On the contrary, combination of BMP4 and Activin A prevented anterior PS formation but favored the posterior PS lineage differentiation. (Hansson et al., 2009, Tada et al., 2005). All together, Activin A and BMP4 signals induce PS in a cooperative manner and the effect of BMP4 on PS induction appears to be Activin A-dependent. After PS formation, Activin A directs cells into the anterior endoderm lineage whereas BMP4 favors the posterior mesoderm lineage. An interplay between these TGF-beta ligands and the WNT pathway certainly operates in the specification of PS, considering that Activin A can induce Wnt3a expression and that continuous stimulation of the WNT pathway alone in mESCs induces a PS-like phenotype and further gives rise to mesoderm cells (Bakre et al., 2007, Nakanishi et al., 2009, Xiao et al., 2006).

Inhibition of FGF receptor signaling reveals a role for FGF on DE formation induced by Activin A (Hansson et al., 2009, Morrison et al., 2008). FGF2 enhances Activin A-induced Gsc expression and this effect is antagonized by FGF receptor inhibition, suggesting that Gsc positive mesendoderm derived from anterior PS requires FGF signaling and that anterior PS fate is further improved by active FGF signaling. Furthermore, DE formation as assessed by Sox17 expression has a late dependence on FGF signaling (Hansson et al., 2009), however further stimulation of the pathway by exogenous FGF does not increase Activin A-induced DE marker expression. This result is not consistent with the observations from another study that addition of FGF ligands at later stages increased the resulting DE population (Morrison et al., 2008), although different induction protocols were applied. Nevertheless, they suggest the involvement of FGF signaling in essential steps of mesendoderm and DE induction.

Whereas all these pathways are known to contribute to a certain extent to PS and $\mathrm{DE}$ formation in vitro, it remained for long challenging to obtain more than 30\% DE differentiation efficiency or to maintain adequate survival of DE precursors in monolayer cultures. It is only recently that the combination of TGF-beta stimulation, WNT stimulation and BMP inhibition was found to efficiently induce DE cells (more than 75\% CxCR4+ cells) in EBs from mESCs (Li et al., 2011). Our personal observations confirmed these findings on monolayer cultures and therefore significantly improved the previously reported efficiencies (Hansson et al., 2009, Morrison et al., 2008). Taken together, Nodal/Activin A, WNT, BMP4 and FGF signals also crosstalk to regulate PS formation and DE specification from mESCs in vitro (Fig. 2). However, we might still be far from understanding how faithfully the current in vitro differentiation systems reproduce all the critical aspects of DE differentiation in vivo, including the cellular spatial organization and intercellular contacts, the timing of growth factors activity and the morphogen effects.

\section{Definitive endoderm differentiation in human ESCs}

The differentiation of DE lineages from hESCs was facilitated by the initial reports on mouse embryo development and on endoderm differentiation from mESCs. It was therefore obvious from these previous models that the four main pathways (Activin/Nodal, BMP,

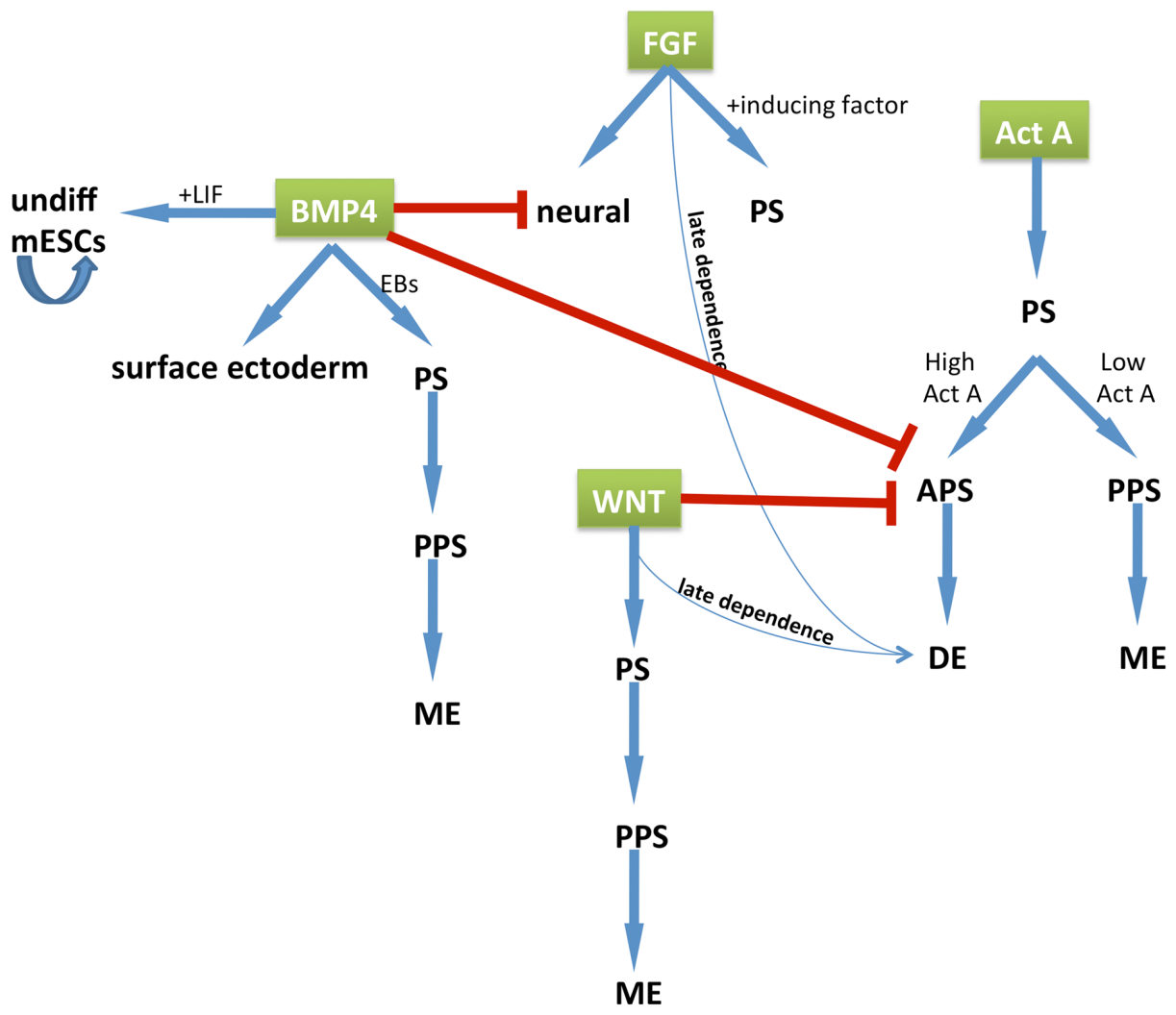

Fig. 2. Schematic representation of the roles played by several signaling pathways on germ layer specification in mESCs. BMP4 induces surface ectoderm. The presence of other factors converts the role of BMP4 into MESCs maintenance and mesoderm induction. FGF induces neural ectoderm by default and augments PS formation synergistically with PS specific inducing factor, like Activin A. WNT contributes to PS induction followed by mesendoderm specification if continuously activated. The low level of Activin A favors mesendoderm formation. The definitive endoderm induced by high Activin A has a late dependence on FGF and WNT signaling. The specification of the anterior PS, which gives rise to the definitive endoderm, is blocked by BMP4 and WNT. 
FGF and WNT) that operate in mouse endoderm differentiation might also be implicated in humans. As described in the following paragraphs, these pathways control DE differentiation from hESCs and also function in a signaling network that operates via molecular and temporal crosstalks between them.

\section{Nodal/Activin A pathway}

In addition to maintaining the undifferentiated state of hESCs, Activin A plays a similar role in germ layer formation as in mESCs by inducing BRY positive mesendoderm formation and by generating DE and mesoderm in a concentration dependent manner (D'Amour et al., 2005, Gadue et al., 2006, Hansson et al., 2009, Kubo et al., 2004). This implies that the functions of TGF-beta signaling in mesoderm and endoderm formation are well conserved from lower to higher vertebrates (Tam et al., 2003, Thisse et al., 2000, Whitman, 2001). However, DE induction by Activin A in monolayer cultures of hESCs is much more efficient than currently reported in mESCs ((D'Amour et al., 2005, Hansson et al., 2009, Morrison et al., 2008) and personal observations). Although FGF and WNT pathways can modulate the extent of DE differentiation, it is remarkable that in the absence of Activin signaling, they could neither maintain hESC pluripotency, nor drive mesendoderm commitment in chemically defined medium (Sui et al., 2012b, Vallier et al., 2009b), (Fig. 3). Therefore, Activin A acts upstream of the other factors that modulate endoderm differentiation, and is absolutely required for the generation of this germ layer. Indeed, inhibition of Activin signaling promotes neuroectoderm differentiation instead of PS/DE (Smith et al., 2008). To this end, Activin A has been extensively used as an essential component in the induction of $\mathrm{DE}$ from hESCs in a number of protocols wherein DE-derived pancreatic cells and hepatocytes were generated (Agarwal et al., 2008, D'Amour et al., 2006, Hay et al., 2008, Kroon et al., 2008, Mfopou et al., 2010a, Xu et al., 2011).
Activin Afunctions by activating the intracellular SMAD2/3 signal transducers. A recent chemical library screening identified small molecules (IDE1, IDE2) that also activate this pathway, resulting in the formation of DE from mESCs and hESCs (Borowiak et al., 2009). In the future the use of such chemical strategies would eliminate the financial and biological hurdles of working with recombinant proteins.

\section{BMP pathway}

BMP4-treated hESCs are unable to generate BRY positive mesendoderm/mesoderm progenitors (Sumi et al., 2008) but give rise to trophectoderm or primitive endoderm in long-term culture (Pera et al., 2004, Vallier et al., 2009b, Xu et al., 2002). This effect of BMP4 is actually dependent on the concomitant decrease in Activin and FGF signaling that normally maintain NANOG expression, given that addition of FGF2 or forced expression of NANOG switches the BMP4-induced differentiation from extraembryonic lineages into mesendoderm (Yu et al., 2011, Zhang et al., 2008). On the contrary, hESCs exposure to BMP4 for a short time (no more than 24h) or after EBs formation generates mesendoderm/ mesoderm progenitors capable of further differentiation into hematopoietic and cardiac lineages (Takei et al., 2009, Zhang et al., 2008), (Fig. 3). Furthermore, BMP4 combined with Activin A synergistically generated endoderm cells expressing FOXA2 and SOX17 from hESCs. These cultures further gave rise to PDX1 and NKX6.1 double positive pancreatic endoderm, indicating the DE nature of the FOXA2+SOX17+ cells generated by these means (Phillips et al., 2007, Teo et al., 2012). Transient stimulation of hESCs with Activin A for one day in combination with BMP4, VEGF and FGF2 was shown to generate multipotent mesoderm progenitors at day 3.5 that have the potential to generate all mesodermal lineages (Evseenko et al., 2010). Therefore, BMP4 can modulate mesendoderm and mesoderm specification from hESCs, and a
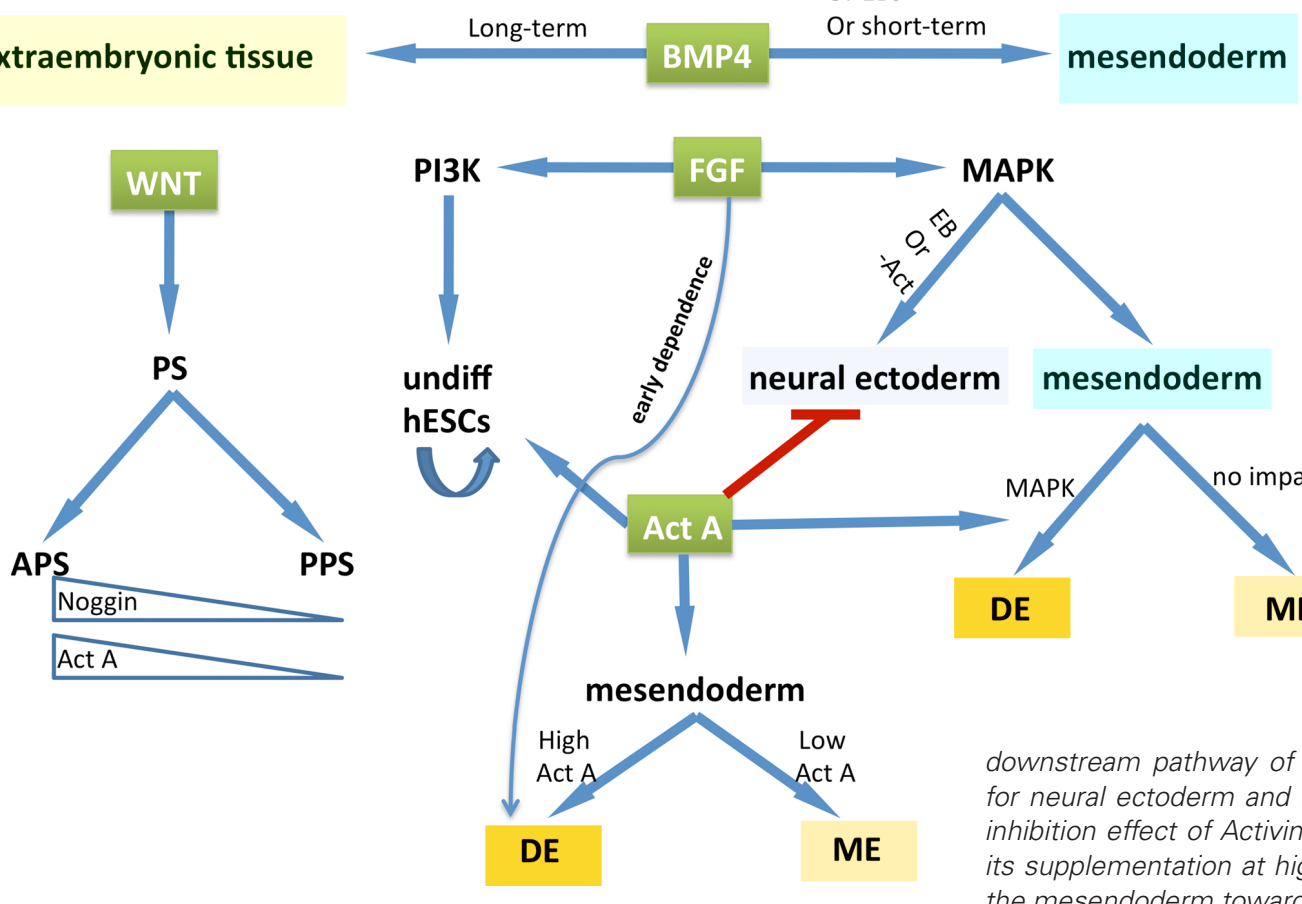

MAPK

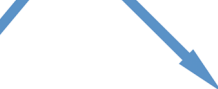

mesendoderm

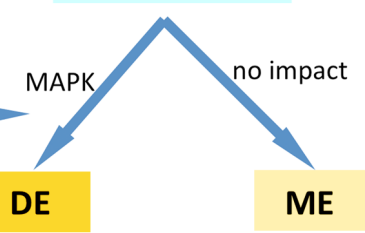

downstream pathway of FGF signaling is mainly responsible for neural ectoderm and mesendoderm derivation. Beside the inhibition effect of Activin A on neural ectoderm development, its supplementation at high concentration could further induce the mesendoderm towards definitive endoderm. 
precise control of its signaling time window and the interplay with additional pathways are pivotal for cell fate determination.

\section{WNT pathway}

The induction of PS and mesendoderm cell types by Activin A is at least in part related to the subsequent activation of WNT3a transcription by this growth factor (Bakre et al., 2007, Kemp et al., 2007, Sumi et al., 2008, Xiao et al., 2006). Indeed, WNT signaling can induce BRY-positive PS formation in serum free condition (Fig. 3); and similar to mESC cultures, continuous exposure to WNT promotes the formation of posterior mesoderm (Sumi et al., 2008). This effect of WNT signaling on posterior PS/mesoderm formation can be shifted towards anterior PS/DE and anterior mesoderm by addition of the BMP antagonist Noggin (Sumi et al., 2008). The PS cells initially induced by WNT can be further directed towards the DE by addition of Activin A and removal of WNT ligands.

Taken together, these data led to the development of an efficient DE induction protocol wherein Activin A and Wnt3a are supplemented to undifferentiated hESCs for a short period (1 or 2 days), followed by Activin A and serum (low concentration) for 2 days (D'Amour et al., 2005). This results in an optimal synchrony in the generation of the mesendoderm population and its further conversion into DE cells, and is considered nowadays as the standard protocol for DE induction from hESCs (Mfopou et al., 2010b). This strategy has been successfully used by several investigators on multiple cell lines including human induced pluripotent stem cells, and the resulting DE cells could be differentiated further into hepatic and pancreatic lineages (D'Amour et al., 2005, D'Amour et al., 2006, Johannesson et al., 2009, Kelly et al., 2011, Kroon et al., 2008, Mfopou et al., 2010a, Nostro et al., 2011, Sui et al., 2012a, Thatava et al., 2011), (Table 3). However, the use of serum supplementation constitutes a disadvantage for the development of clinical grade progenies from this protocol, which stimulated the search for many other alternatives (Table 3).

\section{FGF pathway}

FGF signaling has diverse roles during embryo development depending on the temporal and spatial contexts. Active FGF signaling is required to maintain hESC pluripotency. Blockade of its downstream effector MAPK results in the loss of pluripotency markers and differentiation of primitive endoderm and trophoectoderm (Dvorak et al., 2005, Li et al., 2007). However, recent studies suggest that inhibition of MAPK has no influence on selfrenewal of hESCs, but prevents mesendodermal differentiation (Ding et al., 2010, Na et al., 2010). These observations suggest that MAPK pathway controls the differentiation whereas PI3K, another downstream effector of FGF signaling, is mainly devoted to the regulation of hESC pluripotency. Similarly, the role of FGF on germ layer specification is variable with regards to the context. In the absence of anti-differentiation factors, for instance following depletion of the self-renewal factor Activin A or after formation of EBs, FGF activity induces neuroectodermal differentiation (Cohen et al., 2010, Vallier et al., 2009b). The impact of FGF signaling has been broadly and clearly defined in the maintenance of selfrenewal and in the commitment of neural lineages from hESCs (Fig. 3). However, only few studies reported on the role of FGF in mesendoderm, endoderm and mesoderm derivation from hESCs. It is only recently that independent data from $\mathrm{Na}$ et al., and from our group clearly showed that FGF signaling promotes Activin A-induced DE differentiation in serum free condition, and that its antagonism severely reduces mesendoderm and DE commitment (Na et al., 2010, Sui et al., 2012b). Interestingly, FGF alone also failed to drive DE formation from hESCs (Sui et al., 2012b, Vallier et al., 2009b), indicating that similar to what occurs in mESCs, TGF-beta signaling is required upstream of FGF pathway during mesendoderm/DE differentiation. This suggests that FGF is not a major DE inducing factor, but a synergistic factor that has to be activated to support Activin A-induced DE formation. Concordant with the finding by $\mathrm{Na}$ et al., ( $\mathrm{Na}$ et al., 2010), we also demonstrated that the FGF downstream effector MAPK/ERK, rather than PI3K/ $\mathrm{AKT}$, is crucial for mesendoderm/DE differentiation in the presence of Activin A. However, anterior PS/mesendoderm formation induced by combined WNT activation and BMP inhibition appears to involve PI3K/AKT signaling (Sumi et al., 2008). Although all these studies

TABLE 3

\section{OVERVIEW OF FEW SYSTEMS USED FOR DEFINITIVE ENDODERM DIFFERENTIATION FROM HESCS}

\begin{tabular}{|c|c|c|c|c|}
\hline Parameters in the DE protocol & Efficiency / Advantage & Disadvantage & Differentiated progenitors & References \\
\hline $\begin{array}{l}\text { RPMI - Activin A - WNT - FBS - Feeders or } \\
\text { Matrigel - 3-4 days }\end{array}$ & $\begin{array}{l}80 \% \text { CxCR } 4+\text { cells; } \\
70 \% \text { FOXA2+ SOX } 17+\text { cells }\end{array}$ & $\begin{array}{l}\text { Unknown factors in FBS and Matrigel; } \\
\text { feeders variability }\end{array}$ & Pancreas & $\begin{array}{l}\text { (Ameri et al., D'Amour et al., 2006, } \\
\text { Johannesson et al., 2009, Kroon et } \\
\text { al., 2008, Mfopou et al., 2010a) }\end{array}$ \\
\hline $\begin{array}{l}\text { SFD - EBs - Activin A - BMP4 - VEGF - bFGF - } \\
\text { WNT - } 4 \text { days }\end{array}$ & $70 \%$ SOX $17+$ cells; Defined medium & Stochastic differentiation in EBs & Pancreas & (Nostro et al., 2011) \\
\hline $\begin{array}{l}\text { CDM - Activin A - bFGF - BMP4 - Ly294002 - } 3 \\
\text { days }\end{array}$ & $\begin{array}{l}\text { Defined medium; free of animal } \\
\text { products }\end{array}$ & & Pancreas and liver & (Cho et al., 2012) \\
\hline $\begin{array}{l}\text { CDM - Activin A - BMP4 - bFGF - Fibronectin - } \\
\text { (Ly294002) - - -4 days }\end{array}$ & 70\% CxCR4+ cells; Defined medium & - & - & $\begin{array}{l}\text { (Vallier et al., 2009a, Vallier et al., } \\
2009 b)\end{array}$ \\
\hline RPMI - Activin $\mathrm{A}-\mathrm{NaB}-3-5$ days & $\begin{array}{l}70 \% \text { CxCR4+ cells; } \\
\text { Feeder-free and serum-free }\end{array}$ & Unknown molecular effects of $\mathrm{NaB}$ & Liver & (Hay et al., 2008) \\
\hline $\begin{array}{l}\text { DMEM/F12 - Activin A - bFGF - FBS - EBs on } \\
\text { Matrigel }\end{array}$ & $?$ & Unkwon factors in Matrigel & Liver & (Basma et al., 2009) \\
\hline $\begin{array}{l}\text { CDM - Activin A - Ly294002 - bFGF - BMP4 - } \\
\text { FBS - } 5 \text { days }\end{array}$ & $\begin{array}{l}80 \% \text { CxCR4+ cells; } \\
\text { CDM } \\
\text { Feeder-free }\end{array}$ & Unknown factors in FBS & Liver & (Touboul et al., 2010) \\
\hline DMEM - Activin A - WNT - Collagen IV - 4 days & $87 \%$ CxCR4+ cells; & - & Lung & (Wong et al., 2012) \\
\hline RPMI - Activin A - FBS - 3 days & $\begin{array}{l}90 \% \text { FOXA2+ SOX } 17+\text { cells; } \\
\text { Feeder free }\end{array}$ & Unknown factors in FBS & Intestine & (Spence et al., 2011) \\
\hline
\end{tabular}

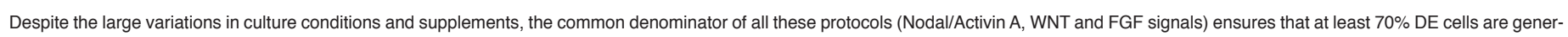
ated. CDM, chemically defined medium; EBs, embryoid bodies; NaB, sodium butyrate; SFD, serum free differentiation medium. 
point towards a role for FGF in Activin A-induced DE differentiation, there are conflicting data about the time window in which this effect occurs. We demonstrated that DE differentiation has an early dependence on FGF signaling on the basis of reduced SOX17 expression after FGF inhibition at early stages (Sui et al., 2012b). In contrast, a late dependence on FGF signaling in both mESCs (Hansson et al., 2009, Morrison et al., 2008) and hESCs (Vallier et al., 2009b) were initially reported. These discrepancies likely result from differences in the models being used in these studies. Worthy to note, one can declare in light of current findings that FGF signaling is necessary but not sufficient for mesendoderm and DE differentiation, and it acts as a complementary factor to support the stimulatory effect of Activin A on DE induction.

\section{Other signaling pathways in germ layer commitment}

In addition to the well-studied pathways described above, Notch and RA pathways might also be implicated in germ layer commitment. The role of Notch signaling in early gastrulation-like events from ESCs is controversial. Loss of Notch signaling promotes mesoderm formation and represses neural lineage specification in mESC culture (Lowell et al., 2006, Nemir et al., 2006). Although Notch pathway antagonism with a gamma-secretase inhibitor does not affect self-renewal and differentiation in standard cultures of hESCs (Fox et al., 2008, Noggle et al., 2006), it induced mesoderm lineages and attenuated neural and hematopoietic commitment in small-volume culture conditions (Jang et al., 2008). However, it was also shown that Notch inhibition downregulates expression of PS markers even in the presence of BMP4, thereby establishing surface ectoderm formation in hESCs and neural formation in mESCs (Hughes et al., 2009). This suggests that culture conditions of ESCs affect their responses to Notch inhibitors, and that blocking this pathway can in certain circumstances induce a lineage that is known to originate from the anterior PS/mesendoderm.

The major findings on the role of RA in germ layer commitment focus on neural ectoderm differentiation in mESCs and point towards a crosstalk of this pathway with FGF signaling (Stavridis et al., 2010, Ying et al., 2003b). Similarly, a study reported the differentiation of pancreatic cells from DE induced in monolayer cultures of mESCs by a combination of RA and FGF2 (Kim et al., 2010). However, the supplementation of $15 \%$ FBS during DE induction does not allow to draw firm conclusions on the contribution of RA signaling.

\section{Concluding remarks}

During long-term culture in vitro, mESCs and hESCs maintain their self-renewal and pluripotency properties via integration of different signaling pathways. Although several common growth factors are expressed in both cell types including WNT and FGF ligands, their role on the regulation of the pluripotent state is quite different (Cohen et al., 2010, Kunath et al., 2007, Sato et al., 2004, ten Berge et al., 2011, Xiao et al., 2006, Ying et al., 2008). For instance, WNT is essential to sustain mESCs pluripotency whereas in hESCs it is only responsible for the proliferation (Dravid et al., 2005, Sato et al., 2004, ten Berge et al., 2011, Wray et al., 2011, Ying et al., 2008). FGF signal in mESCs has to be inhibited to maintain pluripotency whereas in hESCs it has to be activated (Armstrong et al., 2006, Dvorak et al., 2005, Li et al., 2007, Ying et al., 2008). These dramatic discrepancies between mESCs and hESCs re- garding the maintenance of pluripotency are now uncovered and are related to the developmental origins of these pluripotent cells. With regards to this, pluripotent cells derived from rodent embryos at the epiblast stage (EpiSCs, epiblast stem cells) display similar characteristics and requirements with hESCs (Brons et al., 2007, Rossant, 2008, Tesar et al., 2007, Vallier et al., 2009b). This led to the suggestion that hESCs are much closer or equivalent to the postimplantation epiblast rather than to the inner cell mass cells.

Whereas the functions played by Activin A, WNT, FGF and BMP4 pathways during undifferentiated growth are quite different among hESCs and mESCs, their role during early development is conserved to some extent. For instance, Activin A induces DE and mesoderm in a dose-dependent manner in both mouse and human ESCs, with low concentrations driving mesoderm fate and high concentrations favoring anterior endoderm fate. With regards to mesendoderm and DE differentiation, FGF is mainly a competence factor that improves germ layer formation in concert with specific commitment factors and in a particular competence window. Specific protocols developed for each system allow for efficient generation of DE cells that are competent for further differentiation into endoderm progenies such as liver, pancreas, lungs and intestine (Table 3). While they sometimes significantly differ in the use of feeder cells, extracellular matrix, serum or growth factors combinations, these protocols have as common denominator the requirement for Activin/Nodal, WNT and FGF (MAPK/ERK) signaling. These signals can be provided via growth factors or small molecules supplementation, and in certain models are also provided by the feeder cells or serum. Whereas the mesendoderm stage is well described in both systems, it remains unclear for now whether the passage from mESCs to DE involves an earlier EpiSC-like intermediate stage.

Although we aimed at giving an overview of the main differences in the signaling pathways that control pluripotency and early DE commitment in mESCs and hESCs, we have made an effort to keep it short and for this reason we would like to apologize for the investigators whose works have not been covered owing to space limitations. We also have not discussed DE differentiation from EpiSCs, given the recent discovery of these lines. Further work will be needed to foster the integrated understanding of the complex interactions and crosstalk between different pathways involved in endoderm differentiation, and to estimate how faithfully the in vitro implementation of this knowledge recapitulates the in vivo events (Wang et al., 2012). The current development of defined culture conditions and the increasing interest in using small molecules for pathways modulation will certainly affect the future of stem cell differentiation. They will be valuable for further understanding the basics of human embryo development and more interestingly, for the implementation of this knowledge in the development of clinical grade progenies from human pluripotent stem cells.

\section{References}

AGARWAL, S., HOLTON, K.L. and LANZA, R. (2008). Efficient differentiation of functional hepatocytes from human embryonic stem cells. Stem Cells 26: 1117-1127.

AMERI, J., STAHLBERG, A., PEDERSEN, J., JOHANSSON, J.K., JOHANNESSON, M.M., ARTNER, I. and SEMB, H. FGF2 specifies hESC-derived definitive endoderm into foregut/midgut cell lineages in a concentration-dependent manner. Stem Cells 28: 45-56.

ARMSTRONG, L., HUGHES, O., YUNG, S., HYSLOP, L., STEWART, R., WAPPLER, I., PETERS, H., WALTER, T., STOJKOVIC, P., EVANS, J. et al., (2006). The role 
of PI3K/AKT, MAPK/ERK and NFkappabeta signalling in the maintenance of human embryonic stem cell pluripotency and viability highlighted by transcriptional profiling and functional analysis. Hum Mol Genet 15: 1894-1913.

ASSADY, S., MAOR, G., AMIT, M., ITSKOVITZ-ELDOR, J., SKORECKI, K.L. and TZUKERMAN, M. (2001). Insulin production by human embryonic stem cells. Diabetes 50: 1691-1697.

BAKRE, M.M., HOI, A., MONG, J.C., KOH, Y.Y., WONG, K.Y. and STANTON, L.W. (2007). Generation of multipotential mesendodermal progenitors from mouse embryonic stem cells via sustained Wnt pathway activation. J Biol Chem 282: 31703-31712

BARROW, J.R., HOWELL, W.D., RULE, M., HAYASHI, S., THOMAS, K.R., CAPECCHI, M.R. and MCMAHON, A.P. (2007). Wnt3 signaling in the epiblast is required for proper orientation of the anteroposterior axis. Dev Biol 312: 312-320.

BASMA, H., SOTO-GUTIERREZ, A., YANNAM, G.R., LIU, L., ITO, R., YAMAMOTO, T., ELLIS, E., CARSON, S.D., SATO, S., CHEN, Y. et al., (2009). Differentiation and transplantation of human embryonic stem cell-derived hepatocytes. Gastroenterology 136: 990-999.

BEDDINGTON, R.S. and ROBERTSON, E.J. (1989). An assessment of the developmental potential of embryonic stem cells in the midgestation mouse embryo. Development 105: 733-737.

BOROWIAK, M., MAEHR, R., CHEN, S., CHEN, A.E., TANG, W., FOX, J.L., SCHREIBER, S.L. and MELTON, D.A. (2009). Small Molecules Efficiently Direct Endodermal Differentiation of Mouse and Human Embryonic Stem Cells. Cell Stem Cell 4: 348-358.

BRONS, I.G., SMITHERS, L.E., TROTTER, M.W., RUGG-GUNN, P., SUN, B., CHUVA DE SOUSALOPES, S.M., HOWLETT, S.K., CLARKSON, A., AHRLUND-RICHTER, L., PEDERSEN, R.A. et al., (2007). Derivation of pluripotent epiblast stem cells from mammalian embryos. Nature 448: 191-195.

BURDON, T., CHAMBERS, I., STRACEY, C., NIWA, H. and SMITH, A. (1999). Signaling mechanisms regulating self-renewal and differentiation of pluripotent embryonic stem cells. Cells Tissues Organs 165: 131-143.

BURDON, T., SMITH, A. and SAVATIER, P. (2002). Signalling, cell cycle and pluripotency in embryonic stem cells. Trends Cell Biol 12: 432-438.

CAI, J., YU, C., LIU, Y., CHEN, S., GUO, Y., YONG, J., LU, W., DING, M. and DENG, H. (2010). Generation of homogeneous PDX1(+) pancreatic progenitors from human ES cell-derived endoderm cells. J Mol Cell Biol 2: 50-60.

CAMUS, A., PEREA-GOMEZ, A., MOREAU, A. and COLLIGNON, J. (2006). Absence of Nodal signaling promotes precocious neural differentiation in the mouse embryo. Dev Biol 295: 743-755.

CHAMBERS, I. and SMITH, A. (2004). Self-renewal of teratocarcinoma and embryonic stem cells. Oncogene 23: 7150-7160.

CHO, C.H., HANNAN, N.R., DOCHERTY, F.M., DOCHERTY, H.M., JOAO LIMA, M., TROTTER, M.W., DOCHERTY, K. and VALLIER, L. (2012). Inhibition of activin/ nodal signalling is necessary for pancreatic differentiation of human pluripotent stem cells. Diabetologia 55: 3284-3295.

CHO, M.S., LEE, Y.E., KIM, J.Y., CHUNG, S., CHO, Y.H., KIM, D.S., KANG, S.M., LEE, H., KIM, M.H., KIM, J.H. et al., (2008). Highly efficient and large-scale generation of functional dopamine neurons from human embryonic stem cells. Proc Natl Acad Sci USA 105: 3392-3397.

CIRUNA, B. and ROSSANT, J. (2001). FGF signaling regulates mesoderm cell fate specification and morphogenetic movement at the primitive streak. Dev Cell1:37-49.

COHEN, M.A., ITSYKSON, P. and REUBINOFF, B.E. (2010). The role of FGF-signaling in early neural specification of human embryonic stem cells. DevBio/340:450-458.

CONLON, F.L., LYONS, K.M., TAKAESU, N., BARTH, K.S., KISPERT, A., HERRMANN, B. and ROBERTSON, E.J. (1994). A primary requirement for nodal in the formation and maintenance of the primitive streak in the mouse. Development 120: 1919-1928.

D'AMOUR, K.A., AGULNICK, A.D., ELIAZER, S., KELLY, O.G., KROON, E. and BAETGE, E.E. (2005). Efficient differentiation of human embryonic stem cells to definitive endoderm. Nat Biotechnol 23: 1534-1541.

D'AMOUR, K.A., BANG, A.G., ELIAZER, S., KELLY, O.G., AGULNICK, A.D., SMART, N.G., MOORMAN, M.A., KROON, E., CARPENTER, M.K. and BAETGE, E.E. (2006). Production of pancreatic hormone-expressing endocrine cells from human embryonic stem cells. Nat Biotechnol 24: 1392-1401.

DI GIORGIO, F.P., BOULTING, G.L., BOBROWICZ, S. and EGGAN, K.C. (2008). Human embryonic stem cell-derived motor neurons are sensitive to the toxic effect of glial cells carrying an ALS-causing mutation. Cell Stem Cell 3: 637-648. DI-GREGORIO, A., SANCHO, M., STUCKEY, D.W., CROMPTON, L.A., GODWIN, J., MISHINA, Y. and RODRIGUEZ, T.A. (2007). BMP signalling inhibits premature neural differentiation in the mouse embryo. Development 134: 3359-3369.

DING, V.M., LING, L., NATARAJAN, S., YAP, M.G., COOL, S.M. and CHOO, A.B. (2010). FGF-2 modulates Wnt signaling in undifferentiated hESC and iPS cells through activated PI3-K/GSK3beta signaling. J Cell Physiol 225: 417-428.

DRAVID, G., YE, Z., HAMMOND, H., CHEN, G., PYLE, A., DONOVAN, P., YU, X. and CHENG, L. (2005). Defining the role of Wnt/beta-catenin signaling in the survival, proliferation, and self-renewal of human embryonic stem cells. Stem Cells 23: 1489-1501.

DVORAK, P., DVORAKOVA, D., KOSKOVA, S., VODINSKA, M., NAJVIRTOVA, M., KREKAC, D. and HAMPL, A. (2005). Expression and potential role of fibroblast growth factor 2 and its receptors in human embryonic stem cells. Stem Cells 23: $1200-1211$

EVANS, M.J. and KAUFMAN, M.H. (1981). Establishment in culture of pluripotential cells from mouse embryos. Nature 292: 154-156.

EVSEENKO, D., ZHU, Y., SCHENKE-LAYLAND, K., KUO, J., LATOUR, B., GE, S., SCHOLES, J., DRAVID, G., LI, X., MACLELLAN, W.R. et al., (2010). Mapping the first stages of mesoderm commitment during differentiation of human embryonic stem cells. Proc Natl Acad Sci USA 107: 13742-13747.

FOX, V., GOKHALE, P.J., WALSH, J.R., MATIN, M., JONES, M. and ANDREWS, P.W. (2008). Cell-cell signaling through NOTCH regulates human embryonic stem cell proliferation. Stem Cells 26: 715-723.

FUJIWARA, T., DUNN, N.R. and HOGAN, B.L. (2001). Bone morphogenetic protein 4 in the extraembryonic mesoderm is required for allantois development and the localization and survival of primordial germ cells in the mouse. Proc Natl Acad Sci USA 98: 13739-13744.

GADUE, P., HUBER, T.L., PADDISON, P.J. and KELLER, G.M. (2006). Wnt and TGFbeta signaling are required for the induction of an in vitro model of primitive streak formation using embryonic stem cells. Proc Natl Acad Sci USA 103: 16806-16811.

GRANIER, C., GURCHENKOV, V., PEREA-GOMEZ, A., CAMUS, A., OTT, S., PAPANAYOTOU, C., IRANZO, J., MOREAU, A., REID, J., KOENTGES, G. et al., (2011). Nodal cis-regulatory elements reveal epiblast and primitive endoderm heterogeneity in the peri-implantation mouse embryo. Dev Biol 349: 350-362.

GU, Q., HAO, J., ZHAO, X.Y., LI, W., LIU, L., WANG, L., LIU, Z.H. and ZHOU, Q. (2012). Rapid conversion of human ESCs into mouse ESC-like pluripotent state by optimizing culture conditions. Protein Cell 3: 71-79.

HANNA, J., CHENG, A.W., SAHA, K., KIM, J., LENGNER, C.J., SOLDNER, F., CASSADY, J.P., MUFFAT, J., CAREY, B.W. and JAENISCH, R. (2010). Human embryonic stem cells with biological and epigenetic characteristics similar to those of mouse ESCs. Proc Natl Acad Sci USA 107: 9222-9227.

HANSSON, M., OLESEN, D.R., PETERSLUND, J.M., ENGBERG, N., KAHN, M., WINZI, M., KLEIN, T., MADDOX-HYTTEL, P. and SERUP, P. (2009). A late requirement for Wnt and FGF signaling during activin-induced formation of foregut endoderm from mouse embryonic stem cells. Dev Biol 330: 286-304.

HAY, D.C., FLETCHER, J., PAYNE, C., TERRACE, J.D., GALLAGHER, R.C., SNOEYS, J., BLACK, J.R., WOJTACHA, D., SAMUEL, K., HANNOUN, Z. et al., (2008). Highly efficient differentiation of hESCs to functional hepatic endoderm requires ActivinA and Wnt3a signaling. Proc NatIAcad SciUSA 105: 12301-12306.

HAYASHI, Y., FURUE, M.K., TANAKA, S., HIROSE, M., WAKISAKA, N., DANNO, H., OHNUMA, K., OEDA, S., AIHARA, Y., SHIOTA, K. et al., (2010). BMP4 induction of trophoblast from mouse embryonic stem cells in defined culture conditions on laminin. In vitro Cell Dev Biol Anim 46: 416-430.

HOGAN, B.L. (1996). Bone morphogenetic proteins in development. Curr Opin Genet Dev 6: 432-438.

HONDO, E. and STEWART, C.L. (2005). Profiling gene expression in growth-arrested mouse embryos in diapause. Genome Biol 6: 202.

HUGHES, J.N., DODGE, N., RATHJEN, P.D. and RATHJEN, J. (2009). A novel role for gamma-secretase in the formation of primitive streak-like intermediates from ES cells in culture. Stem Cells 27: 2941-2951.

JANG, J., KU, S.Y., KIM, J.E., CHOI, K., KIM, Y.Y., KIM, H.S., OH, S.K., LEE, E.J., CHO, H.J., SONG, Y.H. et al., (2008). Notch inhibition promotes human embryonic stem cell-derived cardiac mesoderm differentiation. Stem Cells 26: 2782-2790.

JIANG, J., AU, M., LU, K., ESHPETER, A., KORBUTT, G., FISK, G. and MAJUMDAR, A.S. (2007a). Generation of insulin-producing islet-like clusters from human 
embryonic stem cells. Stem Cells 25: 1940-1953.

JIANG, W., SHI, Y., ZHAO, D., CHEN, S., YONG, J., ZHANG, J., QING, T., SUN, X., ZHANG, P., DING, M. et al., (2007b). In vitro derivation of functional insulinproducing cells from human embryonic stem cells. Cell Res 17: 333-344.

JOHANNESSON, M., STAHLBERG, A., AMERI, J., SAND, F.W., NORRMAN, K. and SEMB, H. (2009). FGF4 and retinoic acid direct differentiation of hESCs into PDX1-expressing foregut endoderm in a time- and concentration-dependent manner. PLoS One 4: e4794.

KELLY, O.G., CHAN, M.Y., MARTINSON, L.A., KADOYA, K., OSTERTAG, T.M., ROSS, K.G., RICHARDSON, M., CARPENTER, M.K., D'AMOUR, K.A., KROON, E. et al., (2011). Cell-surface markers for the isolation of pancreatic cell types derived from human embryonic stem cells. Nat Biotechnol 29: 750-756.

KEMP, C.R., WILLEMS, E., WAWRZAK, D., HENDRICKX, M., AGBOR AGBOR, T. and LEYNS, L. (2007). Expression of Frizzled5, Frizzled7, and Frizzled10 during early mouse development and interactions with canonical Wnt signaling. Dev Dyn 236: 2011-2019.

KIM, P.T., HOFFMAN, B.G., PLESNER, A., HELGASON, C.D., VERCHERE, C.B., CHUNG, S.W., WARNOCK, G.L., MUI, A.L. and ONG, C.J. (2010). Differentiation of mouse embryonic stem cells into endoderm without embryoid body formation. PLoS One 5: e14146.

KROON, E., MARTINSON, L.A., KADOYA, K., BANG, A.G., KELLY, O.G., ELIAZER, S., YOUNG, H., RICHARDSON, M., SMART, N.G., CUNNINGHAM, J. et al., (2008). Pancreatic endoderm derived from human embryonic stem cells generates glucose-responsive insulin-secreting cells in vivo. Nat Biotechnol 26: 443-452.

KUBO, A., SHINOZAKI, K., SHANNON, J.M., KOUSKOFF, V., KENNEDY, M., WOO, S., FEHLING, H.J. and KELLER, G. (2004). Development of definitive endoderm from embryonic stem cells in culture. Development 131: 1651-1662.

KUNATH, T., SABA-EL-LEIL, M.K., ALMOUSAILLEAKH, M., WRAY, J., MELOCHE, S. and SMITH, A. (2007). FGF stimulation of the Erk1/2 signalling cascade triggers transition of pluripotent embryonic stem cells from self-renewal to lineage commitment. Development 134: 2895-2902.

LAFLAMME, M.A., CHEN, K.Y., NAUMOVA, A.V., MUSKHELI, V., FUGATE, J.A., DUPRAS, S.K., REINECKE, H., XU, C., HASSANIPOUR, M., POLICE, S. et al., (2007). Cardiomyocytes derived from human embryonic stem cells in pro-survival factors enhance function of infarcted rat hearts. Nat Biotechnol 25: 1015-1024.

LANNER, F. and ROSSANT, J. (2010). The role of FGF/Erk signaling in pluripotent cells. Development 137: 3351-3360.

LAWSON, K.A., MENESES, J.J. and PEDERSEN, R.A. (1991). Clonal analysis of epiblast fate during germ layer formation in the mouse embryo. Development 113: 891-911.

LI, F., HE, Z., LI, Y., LIU, P., CHEN, F., WANG, M., ZHU, H., DING, X., WANGENSTEEN, K.J., HU, Y. et al., (2011). Combined activin A/LiCI/Noggin treatment improves production of mouse embryonic stem cell-derived definitive endoderm cells. J Cell Biochem 112: 1022-1034.

LI, J., WANG, G., WANG, C., ZHAO, Y., ZHANG, H., TAN, Z., SONG, Z., DING, M. and DENG, H. (2007). MEK/ERK signaling contributes to the maintenance of human embryonic stem cell self-renewal. Differentiation 75: 299-307.

LIU, P., WAKAMIYA, M., SHEA, M.J., ALBRECHT, U., BEHRINGER, R.R. and BRADLEY, A. (1999). Requirement for Wnt3 in vertebrate axis formation. Nat Genet 22: 361-365.

LOPES, F.L., DESMARAIS, J.A. and MURPHY, B.D. (2004). Embryonic diapause and its regulation. Reproduction 128: 669-678.

LOWELL, S., BENCHOUA, A., HEAVEY, B. and SMITH, A.G. (2006). Notch promotes neural lineage entry by pluripotent embryonic stem cells. PLoS Biol 4: e121.

MARTIN, G.R. (1981). Isolation of a pluripotent cell line from early mouse embryos cultured in medium conditioned by teratocarcinoma stem cells. Proc Natl Acad Sci USA 78: 7634-7638.

MCLEAN, A.B., D'AMOUR, K.A., JONES, K.L., KRISHNAMOORTHY, M., KULIK, M.J., REYNOLDS, D.M., SHEPPARD, A.M., LIU, H., XU, Y., BAETGE, E.E. et al., (2007). Activin a efficiently specifies definitive endoderm from human embryonic stem cells only when phosphatidylinositol 3-kinase signaling is suppressed. Stem Cells 25: 29-38.

MESNARD, D., GUZMAN-AYALA, M. and CONSTAM, D.B. (2006). Nodal specifies embryonic visceral endoderm and sustains pluripotent cells in the epiblast before overt axial patterning. Development 133: 2497-2505.

MFOPOU, J.K., CHEN, B., MATEIZEL, I., SERMON, K. and BOUWENS, L. (2010a).
Noggin, retinoids, and fibroblast growth factor regulate hepatic or pancreatic fate of human embryonic stem cells. Gastroenterology 138: 2233-2245

MFOPOU, J.K., CHEN, B., SUI, L., SERMON, K. and BOUWENS, L. (2010b). Recent advances and prospects in the differentiation of pancreatic cells from human embryonic stem cells. Diabetes 59: 2094-2101.

MORRISON, G.M., OIKONOMOPOULOU, I., MIGUELES, R.P., SONEJI, S., LIVIGNI, A., ENVER, T. and BRICKMAN, J.M. (2008). Anterior definitive endoderm from ESCs reveals a role for FGF signaling. Cell Stem Cell 3: 402-415.

MUELLER, D., SHAMBLOTT, M.J., FOX, H.E., GEARHART, J.D. and MARTIN, L.J. (2005). Transplanted human embryonic germ cell-derived neural stem cells replace neurons and oligodendrocytes in the forebrain of neonatal mice with excitotoxic brain damage. J Neurosci Res 82: 592-608.

MUMMERY, C., VAN DER HEYDEN, M.A., DE BOER, T.P., PASSIER, R., WARD, D., VAN DEN BRINK, S., VAN ROOIJEN, M. and VAN DE STOLPE, A. (2007). Cardiomyocytes from human and mouse embryonic stem cells. Methods Mol Med 140: 249-272.

NA, J., FURUE, M.K. and ANDREWS, P.W. (2010). Inhibition of ERK1/2 prevents neural and mesendodermal differentiation and promotes human embryonic stem cell self-renewal. Stem Cell Res 5: 157-169.

NAKANISHI, M., KURISAKI, A., HAYASHI, Y., WARASHINA, M., ISHIURA, S., KUSUDA-FURUE, M. and ASASHIMA, M. (2009). Directed induction of anterior and posterior primitive streak by Wnt from embryonic stem cells cultured in a chemically defined serum-free medium. FASEB J 23: 114-122.

NAT, R. and DECHANT, G. (2011). Milestones of directed differentiation of mouse and human embryonic stem cells into telencephalic neurons based on neural development in vivo. Stem Cells Dev 20: 947-958.

NEMIR, M., CROQUELOIS, A., PEDRAZZINI, T. and RADTKE, F. (2006). Induction of cardiogenesis in embryonic stem cells via downregulation of Notch1 signaling. Circ Res 98: 1471-1478.

NICHOLS, J., DAVIDSON, D., TAGA, T., YOSHIDA, K., CHAMBERS, I. and SMITH, A. (1996). Complementary tissue-specific expression of LIF and LIF-receptor mRNAs in early mouse embryogenesis. Mech Dev 57: 123-131.

NICHOLS, J., SILVA, J., ROODE, M. and SMITH, A. (2009). Suppression of Erk signalling promotes ground state pluripotency in the mouse embryo. Development 136: 3215-3222.

NOGGLE, S.A., WEILER, D. and CONDIE, B.G. (2006). Notch signaling is inactive but inducible in human embryonic stem cells. Stem Cells 24: 1646-1653.

NOSTRO, M.C., CHENG, X., KELLER, G.M. and GADUE, P. (2008). Wnt, activin, and BMP signaling regulate distinct stages in the developmental pathway from embryonic stem cells to blood. Cell Stem Cell 2: 60-71.

NOSTRO, M.C., SARANGI, F., OGAWA, S., HOLTZINGER, A., CORNEO, B., LI, X., MICALLEF, S.J., PARK, I.H., BASFORD, C., WHEELER, M.B. et al., (2011). Stage-specific signaling through TGFbeta family members and WNT regulates patterning and pancreatic specification of human pluripotent stem cells. Development 138: 861-871.

PARSONS, X.H., TENG, Y.D., PARSONS, J.F., SNYDER, E.Y., SMOTRICH, D.B. and MOORE, D.A. (2011). Efficient derivation of human cardiac precursors and cardiomyocytes from pluripotent human embryonic stem cells with small molecule induction. J Vis Expe3274.

PEARSON, S., SROCZYNSKA, P., LACAUD, G. and KOUSKOFF, V. (2008). The stepwise specification of embryonic stem cells to hematopoietic fate is driven by sequential exposure to Bmp4, activin A, bFGF and VEGF. Development 135: 1525-1535.

PERA, M.F., ANDRADE, J., HOUSSAMI, S., REUBINOFF, B., TROUNSON, A., STANLEY, E.G., WARD-VAN OOSTWAARD, D. and MUMMERY, C. (2004). Regulation of human embryonic stem cell differentiation by BMP-2 and its antagonist noggin. J Cell Sci 117: 1269-1280.

PHILLIPS, B.W., HENTZE, H., RUST, W.L., CHEN, Q.P., CHIPPERFIELD, H., TAN, E.K., ABRAHAM, S., SADASIVAM, A., SOONG, P.L., WANG, S.T. et al., (2007). Directed differentiation of human embryonic stem cells into the pancreatic endocrine lineage. Stem Cells Dev 16: 561-578.

POULAIN, M., FURTHAUER, M., THISSE, B., THISSE, C. and LEPAGE, T. (2006). Zebrafish endoderm formation is regulated by combinatorial Nodal, FGF and BMP signalling. Development 133: 2189-2200.

QI, X., LI, T.G., HAO, J., HU, J., WANG, J., SIMMONS, H., MIURA, S., MISHINA, Y. and ZHAO, G.Q. (2004). BMP4 supports self-renewal of embryonic stem cells 
by inhibiting mitogen-activated protein kinase pathways. Proc Natl Acad Sci USA 101: 6027-6032.

RENFREE, M.B. and SHAW, G. (2000). Diapause. Annu Rev Physiol 62: 353-375.

RODAWAY, A. and PATIENT, R. (2001). Mesendoderm. an ancient germ layer? Cell 105: 169-172.

RODAWAY, A., TAKEDA, H., KOSHIDA, S., BROADBENT, J., PRICE, B., SMITH, J.C., PATIENT, R. and HOLDER, N. (1999). Induction of the mesendoderm in the zebrafish germ ring by yolk cell-derived TGF-beta family signals and discrimination of mesoderm and endoderm by FGF. Development 126: 3067-3078.

ROSSANT, J. (2008). Stem cells and early lineage development. Cell 132: 527-531.

SATO, N., MEIJER, L., SKALTSOUNIS, L., GREENGARD, P. and BRIVANLOU, A.H. (2004). Maintenance of pluripotency in human and mouse embryonic stem cells through activation of Wnt signaling by a pharmacological GSK-3-specific inhibitor. Nat Med 10: 55-63.

SCHIER, A.F. (2003). Nodal signaling in vertebrate development. Annu Rev Cell Dev Biol 19: 589-621.

SCHNERCH, A., CERDAN, C. andBHATIA, M. (2010). Distinguishing between mouse and human pluripotent stem cell regulation: the best laid plans of mice and men. Stem Cells 28: 419-430.

SLACK, J.M. (1994). Inducing factors in Xenopus early embryos. Curr Biol4: 116-126.

SMITH, J.R., VALLIER, L., LUPO, G., ALEXANDER, M., HARRIS, W.A. and PEDERSEN, R.A. (2008). Inhibition of Activin/Nodal signaling promotes specification of human embryonic stem cells into neuroectoderm. Dev Biol 313: 107-117.

SPENCE, J.R., MAYHEW, C.N., RANKIN, S.A., KUHAR, M.F., VALLANCE, J.E., TOLLE, K., HOSKINS, E.E., KALINICHENKO, V.V., WELLS, S.I., ZORN, A.M. et al., (2011). Directed differentiation of human pluripotent stem cells into intestinal tissue in vitro. Nature 470: 105-109.

STAVRIDIS, M.P., COLLINS, B.J. and STOREY, K.G. (2010). Retinoic acid orchestrates fibroblast growth factor signalling to drive embryonic stem cell differentiation. Development 137: 881-890.

STAVRIDIS, M.P., LUNN, J.S., COLLINS, B.J. and STOREY, K.G. (2007). A discrete period of FGF-induced Erk1/2 signalling is required for vertebrate neural specification. Development 134: 2889-2894.

SUI, L., MFOPOU, J.K., CHEN, B., SERMON, K. and BOUWENS, L. (2012a). Transplantation of human embryonic stem cell-derived pancreatic endoderm reveals a site-specific survival, growth and differentiation. Cell Transplant. In press (http:// dx.doi.org/10.3727/096368912X636812)

SUI, L., MFOPOU, J.K., GEENS, M., SERMON, K. and BOUWENS, L. (2012b). FGF signaling via MAPK is required early and improves Activin A-induced definitive endoderm formation from human embryonic stem cells. Biochem Biophys Res Commun 426: 380-385

SUMI, T., TSUNEYOSHI, N., NAKATSUJI, N. and SUEMORI, H. (2008). Defining early lineage specification of human embryonic stem cells by the orchestrated balance of canonical Wnt/beta-catenin, Activin/Nodal and BMP signaling. Development 135: 2969-2979.

TADA, S., ERA, T., FURUSAWA, C., SAKURAI, H., NISHIKAWA, S., KINOSHITA, M., NAKAO, K., CHIBA, T. and NISHIKAWA, S. (2005). Characterization of mesendoderm: a diverging point of the definitive endoderm and mesoderm in embryonic stem cell differentiation culture. Development 132: 4363-4374.

TAKEI, S., ICHIKAWA, H., JOHKURA, K., MOGI, A., NO, H., YOSHIE, S., TOMOTSUNE, D. and SASAKI, K. (2009). Bone morphogenetic protein-4 promotes induction of cardiomyocytes from human embryonic stem cells in serum-based embryoid body development. Am J Physiol Heart Circ Physiol 296: H1793-1803.

TAM, P.P., KANAI-AZUMA, M. and KANAI, Y. (2003). Early endoderm development in vertebrates: lineage differentiation and morphogenetic function. Curr Opin Genet Dev 13: 393-400.

TEN BERGE, D., KUREK, D., BLAUWKAMP, T., KOOLE, W., MAAS, A., EROGLU, E., SIU, R.K. and NUSSE, R. (2011). Embryonic stem cells require Wnt proteins to prevent differentiation to epiblast stem cells. Nat Cell Biol 13: 1070-1075.

TEO, A.K., ALI, Y., WONG, K.Y., CHIPPERFIELD, H., SADASIVAM, A., POOBALAN, Y., TAN, E.K., WANG, S.T., ABRAHAM, S., TSUNEYOSHI, N. et al., (2012). Activin and BMP4 synergistically promote formation of definitive endoderm in human embryonic stem cells. Stem Cells 30: 631-642.

TESAR, P.J., CHENOWETH, J.G., BROOK, F.A., DAVIES, T.J., EVANS, E.P., MACK, D.L., GARDNER, R.L. and MCKAY, R.D. (2007). New cell lines from mouse epiblast share defining features with human embryonic stem cells. Nature 448: 196-199.
THATAVA, T., NELSON, T.J., EDUKULLA, R., SAKUMA, T., OHMINE, S., TONNE, J.M., YAMADA, S., KUDVA, Y., TERZIC, A. and IKEDA, Y. (2011). Indolactam V/GLP-1-mediated differentiation of human iPS cells into glucose-responsive insulin-secreting progeny. Gene Ther 18: 283-293.

THISSE, B., WRIGHT, C.V. and THISSE, C. (2000). Activin- and Nodal-related factors control antero-posterior patterning of the zebrafish embryo. Nature 403: 425-428.

THOMSON, J.A., ITSKOVITZ-ELDOR, J., SHAPIRO, S.S., WAKNITZ, M.A., SWIERGIEL, J.J., MARSHALL, V.S. and JONES, J.M. (1998). Embryonic stem cell lines derived from human blastocysts. Science 282: 1145-1147.

TOUBOUL, T., HANNAN, N.R., CORBINEAU, S., MARTINEZ, A., MARTINET, C. BRANCHEREAU, S., MAINOT, S., STRICK-MARCHAND, H., PEDERSEN, R., DI SANTO, J. et al., (2010). Generation of functional hepatocytes from human embryonic stem cells under chemically defined conditions that recapitulate liver development. Hepatology 51: 1754-1765.

VALLIER, L., ALEXANDER, M. and PEDERSEN, R.A. (2005). Activin/Nodal and FGF pathways cooperate to maintain pluripotency of human embryonic stem cells. $J$ Cell Sci 118: 4495-4509.

VALLIER, L., TOUBOUL, T., BROWN, S., CHO, C., BILICAN, B., ALEXANDER, M., CEDERVALL, J., CHANDRAN, S., AHRLUND-RICHTER, L., WEBER, A. et al., (2009a). Signaling pathways controlling pluripotency and early cell fate decisions of human induced pluripotent stem cells. Stem Cells 27: 2655-2666.

VALLIER, L., TOUBOUL, T., CHNG, Z., BRIMPARI, M., HANNAN, N., MILLAN, E., SMITHERS, L.E., TROTTER, M., RUGG-GUNN, P., WEBER, A. et al., (2009b). Early cell fate decisions of human embryonic stem cells and mouse epiblast stem cells are controlled by the same signalling pathways. PLoS One 4: e6082.

WANG, P., MCKNIGHT, K.D., WONG, D.J., RODRIGUEZ, R.T., SUGIYAMA, T., GU, X., GHODASARA, A., QU, K., CHANG, H.Y. and KIM, S.K. (2012). A molecular signature for purified definitive endoderm guides differentiation and isolation of endoderm from mouse and human embryonic stem cells. Stem Cells Dev 21: 2273-2287.

WELLS, J.M. and MELTON, D.A. (1999). Vertebrate endoderm development. Annu Rev Cell Dev Biol 15: 393-410.

WHITMAN, M. (2001). Nodal signaling in early vertebrate embryos: themes and variations. Dev Cell 1: 605-617.

WILLIAMS, R.L., HILTON, D.J., PEASE, S., WILLSON, T.A., STEWART, C.L., GEARING, D.P., WAGNER, E.F., METCALF, D., NICOLA, N.A. and GOUGH, N.M. (1988). Myeloid leukaemia inhibitory factor maintains the developmental potential of embryonic stem cells. Nature 336: 684-687.

WONG, A.P., BEAR, C.E., CHIN, S., PASCERI, P., THOMPSON, T.O., HUAN, L.J., RATJEN, F., ELLIS, J. and ROSSANT, J. (2012). Directed differentiation of human pluripotent stem cells into mature airway epithelia expressing functional CFTRTR protein. Nat Biotechnol 30: 876-882.

WRAY, J., KALKAN, T., GOMEZ-LOPEZ, S., ECKARDT, D., COOK, A., KEMLER, R. and SMITH, A. (2011). Inhibition of glycogen synthase kinase-3 alleviates Tcf3 repression of the pluripotency network and increases embryonic stem cell resistance to differentiation. Nat Cell Biol 13: 838-845.

XIAO, L., YUAN, X. and SHARKIS, S.J. (2006). Activin A maintains self-renewal and regulates fibroblast growth factor, Wnt, and bone morphogenic protein pathways in human embryonic stem cells. Stem Cells 24: 1476-1486.

XU, R.H., CHEN, X., LI, D.S., LI, R., ADDICKS, G.C., GLENNON, C., ZWAKA, T.P. and THOMSON, J.A. (2002). BMP4 initiates human embryonic stem cell differentiation to trophoblast. Nat Biotechnol 20: 1261-1264.

XU, X., BROWNING, V.L. and ODORICO, J.S. (2011). Activin, BMP and FGF pathways cooperate to promote endoderm and pancreatic lineage cell differentiation from human embryonic stem cells. Mech Dev 128: 412-427.

XU, X.Q., SOO, S.Y., SUN, W. and ZWEIGERDT, R. (2009). Global expression profile of highly enriched cardiomyocytes derived from human embryonic stem cells. Stem Cells 27: 2163-2174.

YASUNAGA, M., TADA, S., TORIKAI-NISHIKAWA, S., NAKANO, Y., OKADA, M., JAKT, L.M., NISHIKAWA, S., CHIBA, T. and ERA, T. (2005). Induction and monitoring of definitive and visceral endoderm differentiation of mouse ES cells. Nat Biotechnol 23: 1542-1550.

YING, Q.L., NICHOLS, J., CHAMBERS, I. and SMITH, A. (2003a). BMP induction of Id proteins suppresses differentiation and sustains embryonic stem cell selfrenewal in collaboration with STAT3. Cell 115: 281-292.

YING, Q.L., STAVRIDIS, M., GRIFFITHS, D., LI, M. and SMITH, A. (2003b). Con- 
version of embryonic stem cells into neuroectodermal precursors in adherent monoculture. Nat Biotechnol 21: 183-186.

YING, Q.L., WRAY, J., NICHOLS, J., BATLLE-MORERA, L., DOBLE, B., WOODGETT, J., COHEN, P. and SMITH, A. (2008). The ground state of embryonic stem cell self-renewal. Nature 453: 519-523.

YU, P., PAN, G., YU, J. and THOMSON, J.A. (2011). FGF2 sustains NANOG and switches the outcome of BMP4-induced human embryonic stem cell differentiation. Cell Stem Cell 8: 326-334

ZHANG, D., JIANG, W., LIU, M., SUI, X., YIN, X., CHEN, S., SHI, Y. and DENG, H. (2009). Highly efficient differentiation of human ES cells and iPS cells into mature pancreatic insulin-producing cells. Cell Res 19: 429-438.
ZHANG, P., LI, J., TAN, Z., WANG, C., LIU, T., CHEN, L., YONG, J., JIANG, W., SUN, X., DU, L. et al., (2008). Short-term BMP-4 treatment initiates mesoderm induction in human embryonic stem cells. Blood 111: 1933-1941.

ZHENG, Z., DE IONGH, R.U., RATHJEN, P.D. and RATHJEN, J. (2010). A requirement for FGF signalling in the formation of primitive streak-like intermediates from primitive ectoderm in culture. PLoS One 5: e12555

ZHOU, H., LI, W., ZHU, S., JOO, J.Y., DO, J.T., XIONG, W., KIM, J.B., ZHANG, K., SCHOLER, H.R. and DING, S. (2010). Conversion of mouse epiblast stem cells to an earlier pluripotency state by small molecules. J Biol Chem 285: 29676-29680.

ZHOU, X., SASAKI, H., LOWE, L., HOGAN, B.L. and KUEHN, M.R. (1993). Noda is a novel TGF-beta-like gene expressed in the mouse node during gastrulation. Nature 361: 543-547.

\section{Further Related Reading, published previously in the Int. J. Dev. Biol.}

Induction of differentiation of undifferentiated cells into pancreatic beta cells in vertebrates Masaki Hosoya, Yuya Kunisada, Akira Kurisaki and Makoto Asashima Int. J. Dev. Biol. (2012) 56: 313-323

\section{Sox17-dependent gene expression and early heart and gut development in Sox17-deficient mouse embryos}

Sabine Pfister, Vanessa J. Jones, Melinda Power, Germaine L. Truisi, Poh-Lynn Khoo, Kirsten A. Steiner, Masami Kanai-Azuma, Yoshiakira Kanai, Patrick P. L. Tam and David A. F. Loebel

Int. J. Dev. Biol. (2011) 55: 45-58

Pdx1-transfected adipose tissue-derived stem cells differentiate into insulin-producing cells in vivo and reduce hyperglycemia in diabetic mice

Hiromitsu Kajiyama, Tatsuo S. Hamazaki, Makoto Tokuhara, Shinji Masui, Koji Okabayashi, Kiyoshi Ohnuma, Shigeharu Yabe, Kazuki Yasuda, Shoichi Ishiura, Hitoshi Okochi and Makoto Asashima

Int. J. Dev. Biol. (2010) 54: 699-705

Characterization of mouse embryonic stem cell differentiation into the pancreatic lineage in vitro by transcriptional profiling, quantitative RT-PCR and immunocytochemistry Alexandra Rolletschek, Insa S. Schroeder, Herbert Schulz, Oliver Hummel, Norbert Huebner and Anna M. Wobus

Int. J. Dev. Biol. (2010) 54: 41-54

Expression of regulatory genes for pancreas development during murine embryonic stem cell differentiation

Josué K. Mfopou, Erik Willems, Luc Leyns and Luc Bouwens

Int. J. Dev. Biol. (2005) 49: 915-922

5 yr ISI Impact Factor $(2011)=2.959$

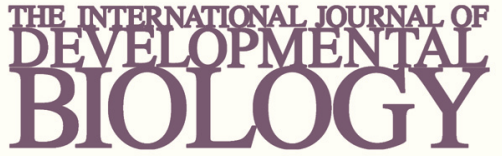

Volume 54 Nos. $6 / 7$
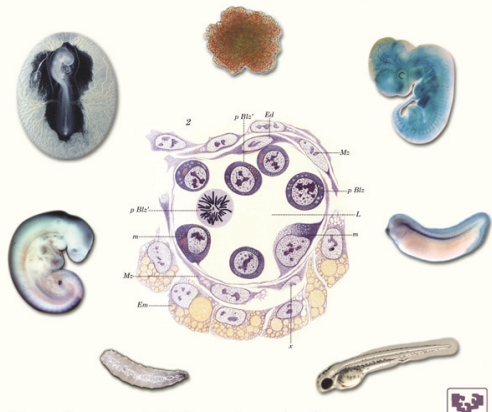

Developmental Hematopoiesis

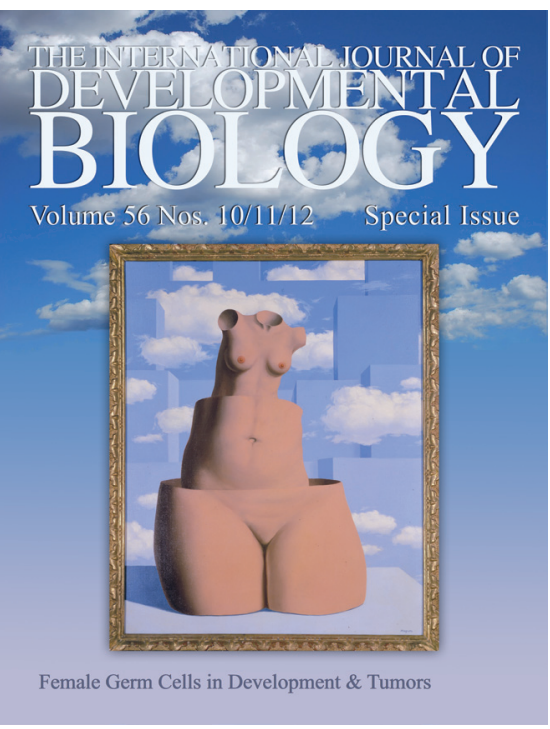

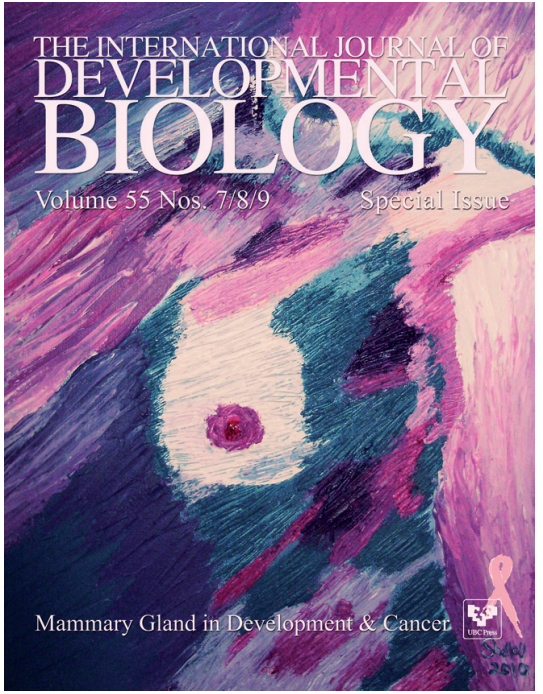

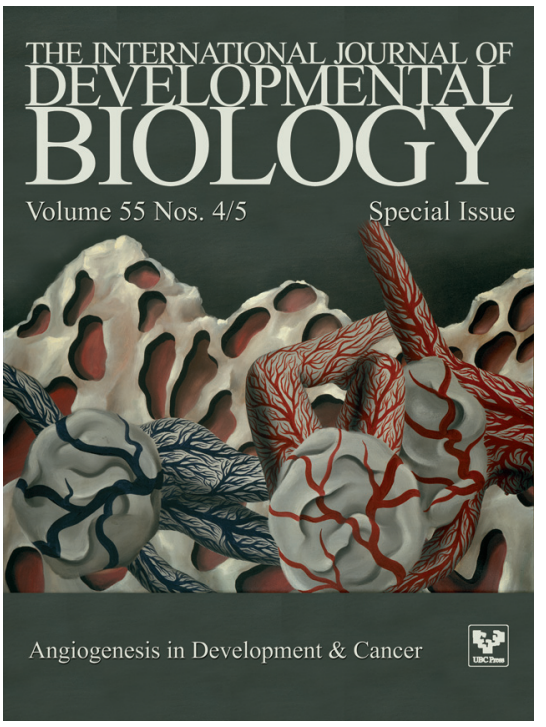

